\title{
Status and Prospect of Clean Cookstoves in Terai Region of Nepal
}

\author{
Hari Bahadur Darlami, Suvita Jha, Bishnu Kumari Budha
}

\begin{abstract}
Energy for cooking is the basic requirement for human society. Type of fuel and its technology keeps importance socially, economically and environmentally. In Terai region of Nepal, diversified fuel is used and most of people are using biomass based fuel in traditional cookstove. In Terai Disticts, Traditional cookstove (TCS), Improved Cookstove (ICS), Rocket stove, Biogas stove, Kerosene stove, LPG stove and induction stove user households have been found $1,600,000 ; 37,000,6,000,90,000 ; 17,000 ; 1,107,000$ and 12,000 respectively. Grid connection, biogas potential and fuelwood available households have been found $89.6 \%, 44 \%$ and $45 \%$ respectively. Total potential ICS, biogas and induction stove promotion potential have been found 679,8400; 249,750 and 536,390 respectively. Most of people are using biomass based cookstove in traditional cooking device which can be replaced by as per their capacity and plan and policies of government sector.
\end{abstract}

Keywords: Traditional cookstove, Improved cookstove, biogas, induction cookstove

\section{INTRODUCTION}

It is estimated from the historical evidences that fire has been used for cooking of meals for about 100,000 years [1]. About 2.6 billion people do not have access to clean cooking facilities; and if predictions are believed the approximately same number will still be so in 2030 [2]. Pollutants emitted from cookstoves cause serious indoor air pollution and have a negative impact on health of people. [3]. About half the people across the world use different types of biomass fuels, to cook a large number of dishes in diverse ways. [4]. The heavy dependency on traditional biomass technology has caused the social burden on majority women and children [5]. About 1.6 million people have premature death per year from indoor air pollution [6]. Venkataraman et al. found that solid biofuel combustion is the dominant source of global black carbon emissions [7]. Linkages between household energy technology, indoor air pollution, and greenhouse gas (GHG) emissions have become increasingly important in understanding the local and global environmental and health effects of domestic energy use [8].

Biomass is a renewable source of energy, traditional biomass stoves cause significant greenhouse gas (GHG) emissions due to formation of products of incomplete combustion; also, exposure to smoke and causes serious

Hari Bahadur Darlami, Department of Mechanical Engineering, Institute of Engineering, Pulchowk Campus, Tribhuvan University, Lalitpur, Nepal.

Suvita Jha, Kathfort International College of Engineering, Tribhuvan University, Lalitpur, Nepal

Bishnu Kumari Budha, National Basic School, Kathmandu, Nepal health problems [9]. The national policies should be in the favor of cheap and efficient cookstove availability to biomass using families [10]. Sheela Pradhan, (2006) has studied on impact of improved cooking stove on rural livelihood and found that two pot hole improved cookstove is highly accepted in the rural area where fuelwood is available [11]. Multiple cooking fuels are used in nearly all households, although wood is the dominant fuel source. [12].

More than 50\% population of Nepal are staying in Terai region, southern part of Nepal [13]. With the low availability of firewood mostly direct burning of animal dung cakes (dried cattle dung: Guintha) and/or burning of agricultural residues and remains (leaves, stems and foliage) of trees and shrubs as fuel for cooking are using by low income people [14]. "Animal Dung Cake" is considered to be the most polluting fuel for cooking and it is the cause of destruction of high quality fertilizer. Usually, it is used by the poorest of the poor people. The dung cakes are produced at the household level and burnt in traditional open fires or mud stoves, resulting emission of hundreds of health hazards pollutants to which women and young children are exposed on a daily basis [15]. In Nepal, traditional energy sources have the highest share accounting 299.7 million GJ in the national energy demand and into this fuel-wood has the major contribution [16].

The share of rural population in Nepal is $87 \%$ [17]. More than 431 thousands household biogas plants, above 1,434 thousands Improved Cook Stoves and more than 2 thousand solar cookers/dryers across the country have been installed [14]. About $77 \%$ of energy consumption of Nepal is supplied by traditional biomass energy technologies and most of energy consumed in the domestic sector for cooking purpose [18]. Alternative Energy Promotion Center (AEPC) has policies for supporting to buy clean cooking device and developed the delivery mechanism [19].

There are several options to improve this precarious situation, like use of induction electric cook stoves where there is sufficient electricity availability with suitable infrastructure, biogas technology, replacement of direct burning of dung with biomass briquettes, use of stoves that aid in better fuel combustion, etc. However, acceptance of any particular stove or energy technology for that matter depends on various aspects like availability and price of fuel, socio-cultural and ethnic values and practices, geographic and climatic conditions, cooking behaviors and practices, kitchen design and management, economic status 
etc. Thus, the developing nations have to think about different strategies and method to meet their requirement by utilizing the renewable energy sources available in their geographical area [20].

Hierarchy of cooking device starts form use of traditional cookstove using biofuel and use of induction stove at highest level of clean cooking solution shown in Figure 1.

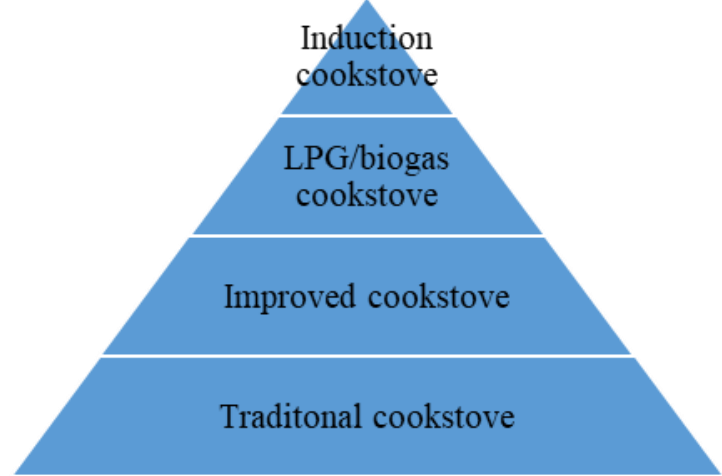

Figure 1: Hierchy of cookstove

The main purpose of this study is to prepare in-detail baseline status of local levels so as to promote higher hierarchy of cooking fuel and technology in Terai Districts of Nepal with integrating life style, living standard of people, local level and government plan and policies.

\section{METHODOLOGY}

The secondary data have been collected for all the 284 Local Levels of 22 Terai districts through various sources. Then, each and every local levels were contacted through phone and email to inform them about the basic concept of the study. The field visit was conducted in each local levels for data collection and organized focal group meeting. During the focal group meeting, cooking technology, available resources, technologies and institutions working in clean cooking sector, suitability of tier-3 and above clean cooking solutions, gap between demand \& supply, annual physical targets of clean cooking solutions for the district were discussed. The filled up questionnaire with collected data was mailed to the local level for the cross checking. The final data obtained from the local levels were validated using secondary information from various sources like Central Bureau of Statistics, Nepal Electricity Authority, and Alternative Energy Promotion Center etc. The shift towards clean cooking has been planned based on data and focal group discussion with respective local levels. Finally, plan for local level has made with the consideration of available resource and discussion with local levels during the field visit.

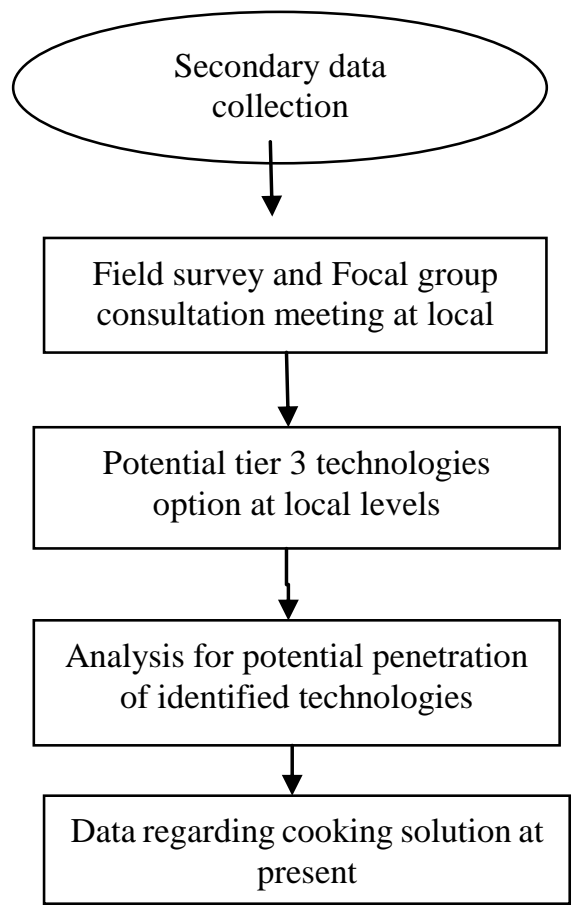

Figure 2: Field visit plan

Following assumptions and limitations has been taken for the analysis are as follows

- This study is based on information from focus group discussions and data provided by local levels.

- Case study and sampling has not taken

- Due to multiple fuel user, total cooking technology user household is more than actual household.

\section{RESULTS AND DISCUSSIONS}

Assessment of energy resources and current status of cooking device has been taken. Then based on current status, potential resources and plan of local and government level, promotion plan has been developed.

\section{A. Assessment of energy resources}

Assessment of availability of energy resources is one of the important factor for the promotion of technology. In the Terai region, main potential energy resource for cooking are grid electricity, fuelwood and biogas. Now most of the people are using imported LPG for cooking purpose.

Table 1: Availability of energy resources

(In '000)

\begin{tabular}{|r|l|r|r|r|c|}
\hline \multicolumn{1}{l|}{ S.N } & \multirow{2}{*}{ District } & \multicolumn{4}{|c|}{ Households } \\
\cline { 3 - 6 } & & Nos. & $\begin{array}{c}\text { Grid } \\
\text { cone- } \\
\text { cted }\end{array}$ & $\begin{array}{c}\text { Biogas } \\
\text { potential }\end{array}$ & $\begin{array}{c}\text { Fuel } \\
\text { wood } \\
\text { potential }\end{array}$ \\
\hline 1. & Jhapa & 205 & 198 & 123 & 99 \\
\hline 2. & Morang & 218 & 208 & 96 & 78 \\
\hline 3. & Sunsari & 168 & 165 & 73 & 44 \\
\hline
\end{tabular}




\begin{tabular}{|c|c|c|c|c|c|}
\hline \multirow{2}{*}{ S.N } & \multirow[t]{2}{*}{ District } & \multicolumn{4}{|c|}{ Households } \\
\hline & & Nos. & $\begin{array}{c}\text { Grid } \\
\text { cone- } \\
\text { cted }\end{array}$ & $\begin{array}{c}\text { Biogas } \\
\text { potential }\end{array}$ & $\begin{array}{c}\text { Fuel } \\
\text { wood } \\
\text { potential }\end{array}$ \\
\hline 4. & Udaypur & 69 & 46 & 51 & 32 \\
\hline 5. & Siraha & 126 & 115 & 54 & 67 \\
\hline 6. & Saptari & 128 & 124 & 63 & 61 \\
\hline 7. & Dhanusha & 138 & 125 & 58 & 62 \\
\hline 8. & Bara & 112 & 99 & 35 & 50 \\
\hline 9. & Parsa & 326 & 289 & 94 & 143 \\
\hline 10. & Rautahat & 117 & 103 & 48 & 46 \\
\hline 11. & Sarlahi & 142 & 126 & 82 & 54 \\
\hline 12. & Mahottari & 114 & 103 & 58 & 42 \\
\hline 13. & Chitwan & 136 & 123 & 46 & 52 \\
\hline 14. & Banke & 102 & 81 & 35 & 56 \\
\hline 15. & Bardiya & 96 & 84 & 47 & 66 \\
\hline 16. & Dang & 123 & 97 & 66 & 72 \\
\hline 17. & Kapilvastu & 94 & 81 & 45 & 60 \\
\hline 18. & Rupandehi & 180 & 169 & 59 & 43 \\
\hline 19. & Nawalpur & 73 & 62 & 29 & 45 \\
\hline 20. & Parasi & 67 & 63 & 19 & 23 \\
\hline 21. & Kanchanpur & 89 & 73 & 53 & 55 \\
\hline 22. & Kailali & 158 & 132 & 76 & 96 \\
\hline & Total & 2,979 & 2,667 & 1,310 & 1,346 \\
\hline
\end{tabular}

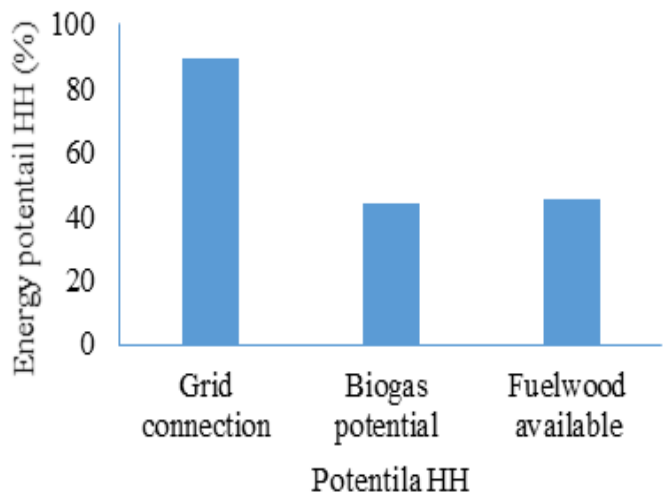

Figure 1: Energy potential households

While looking cooking energy resoruces, most of people have grid connection. Grid electricity is used lighting and domestic applications. But still people are lagging to use elctricity for cooking purpose. There are few reasons behind it (a) low econimic status of user (b) low size of the meter and conductor (c) low voltage, unreliability of electricity (d) practice, lack of awareness and unavailable of induction stove and accessories. Specially, very poor people are using loose biomass and dung cake. Biogas has great potential in Terai Districts. Most of family have small land, involving for farming and cultivation. Climatic condition for biogas production also but biogas is not promoting in Terai because of (a) lack of biogas companies in the Terai region (b) lack of awareness (c) low focal by local bodies and government institutions. Poor people have potential but they don't have capacity to construct biogas plant and the other hand higher level family are using LPG. Middle family are installing biogas plants. Very few people are using induction stove and now it is growing trend.

\section{B. STATUS OF COOKING SOLUTION}

Status of fuel used for cooking purpose and installed cooking technology keeps importance to access the social status, use of local resources and to develop the plan and policies for renewable energy technology development in the local level. Current status of cooking fuel and technology in Terai region has been accessed by collecting data from local level and other secondary sources of information.

Table 2: Current status of cooking solution in Terai Districts

(In '000)

\begin{tabular}{|r|l|r|r|r|r|r|r|r|l|}
\hline S. & District & \multicolumn{1}{l|}{ TCS } & ICS & \multicolumn{1}{l|}{ Rocket } & \multicolumn{1}{l|}{ Biogas } & Kerosene & LPG & Induction & other \\
slant & & & & & & stove & \\
\hline 1. & Jhapa & 100.82 & 3.43 & 0.77 & 13.21 & 0.03 & 103.57 & 1.41 & \\
\hline 2. & Morang & 103.77 & 0.62 & 1.76 & 7.97 & 0.46 & 08.73 & 0.12 & \\
\hline 3. & Sunsari & 74.09 & 0.75 & 1.33 & 2.39 & 0.27 & 91.24 & 6.53 & \\
\hline 4. & Udaypur & 42.89 & 1.99 & 0.04 & 1.82 & & 23.11 & & \\
\hline
\end{tabular}




\begin{tabular}{|c|c|c|c|c|c|c|c|c|c|}
\hline 5. & Siraha & 79.46 & 4.04 & 0.04 & 1.63 & 0.15 & 56.55 & 0.50 & \\
\hline 6. & Saptari & 89.47 & 1.13 & - & 1.85 & 0.26 & 39.65 & 0.82 & \\
\hline 7. & Dhanusha & 96.20 & & & 0.14 & 0.16 & 42.29 & 0.12 & \\
\hline 8. & Bara & 80.49 & 2.41 & 0.20 & 0.77 & 1.39 & 24.77 & 0.20 & 2.03 \\
\hline 9. & Parsa & 69.54 & 0.91 & 0.04 & 0.29 & 0.59 & 36.72 & 0.45 & 0.28 \\
\hline 10. & Rautahat & 90.77 & 0.10 & & 1.44 & 0.81 & 24.94 & 0.05 & 1.39 \\
\hline 11. & Sarlahi & 101.42 & 1.29 & 0.51 & 1.03 & 2.28 & 40.34 & 0.05 & 0.31 \\
\hline 12. & Mahottari & 77.51 & 0.53 & 0.06 & 0.33 & 0.30 & 32.82 & 0.03 & 2.84 \\
\hline 13 & Chitwan & 27.24 & 1.22 & 0.30 & 9.25 & 0.73 & 104.90 & 0.19 & 0.05 \\
\hline 14. & Banke & 57 & & & 1.77 & 0.23 & 42.37 & 0.24 & 0.18 \\
\hline 15. & Bardiya & 69.46 & 1.51 & & 8.26 & 0.16 & 18.80 & 0.15 & 0.02 \\
\hline 16. & Dang & 75.69 & 2.63 & & 4.75 & 3.42 & 41.29 & 0.23 & 0.20 \\
\hline 17. & Kapilvastu & 68.93 & 0.33 & & 3.21 & 0.49 & 20.94 & 0.02 & 0.20 \\
\hline 18. & Rupandehi & 66.71 & 4.30 & 0.47 & 4.81 & 5.00 & 106.70 & 0.23 & \\
\hline 19. & Nawalpur & 34.64 & 3.16 & 0.23 & 3.47 & 0.12 & 36.06 & 0.04 & \\
\hline 20. & Parasi & 36.17 & 1.08 & 0.09 & 1.73 & 0.14 & 28.25 & & \\
\hline 21. & Kanchanpur & 53.82 & 3.50 & & 8.01 & 0.07 & 37.79 & 0.05 & \\
\hline 22. & Kailali & 104.06 & 2.42 & & 11.86 & 0.18 & 45.19 & 0.21 & \\
\hline & Total & 1,600 & 37 & 6 & 90 & 17 & 1,107 & 12 & 8 \\
\hline
\end{tabular}

Overall 1,600,000 households still use TCS as their primary source of cooking in 284 local levels of 22 districts of Terai region of Nepal. The maximum TCS users has been found in Kailai District $(104,000)$ and minimum in Chitwan District $(27,200)$. Similarly, maximum and minimum LPG user have been found in Morang $(108,700)$ and Bardiya $(18,800)$ respectively. The cleaner cookstove such as ICS, Rocket and biogas which are cleaner technology is generally available in the northern part of Terai. ICS and Rocket stove user has been found 37,000 and 6,000 respectively. Total biogas plant user has been found 90,000 in Terai Districts. They are heavy dependent in imported fuel such as Kerosene and LPG by using 17,000 and 1,157,000 households respectively. Very few people are using induction stove in Terai Districts and now in increasing trend. Overall, 1,600,000 households still use TCS as their primary source of cooking in 284 local levels of 22 districts of Terai region of Nepal. The maximum TCS users has been found in Kailai District $(104,000)$ and minimum in Chitwan District $(27,200)$. Similarly, maximum and minimum LPG user have been found in Morang $(108,700)$ and Bardiya $(18,800)$ respectively. The cleaner cookstove such as ICS, Rocket and biogas which are cleaner technology is generally available in the northern part of Terai. ICS and Rocket stove user has been found 37,000 and 6,000 respectively. Total biogas plant user has been found 90,000 in Terai Districts. They are heavy dependent in imported fuel such as Kerosene and LPG by using 17,000 and 1,157,000 households respectively. 
Very few people are using induction stove in Terai Districts and now in increasing trend. Looking at the specific cookstoves within Terai districs, LPG stove is the most commonly used modern cooking solution. As for the traditional cooking solutions, traditional self-built stoves with a variety of basic fuels, namely fuelwood, dry dung and crop residue is still very common in Morang District.

Considering the very high share of households currently using traditional cookstoves, a transition towards ICS could result in great potential benefits. Most of the people are using biomass based fuelwood for cooking. In Terai Districts, about $74 \%$ people are using biomass based fuel and while seeing its resources only $45 \%$ people have access to fuelwood so most of family are using loose biomass and dung cake for cooking purpose.

The penetration potential of clean cooking solutions appears to be large in Terai Districts. Increasing the use of improved cookstoves and biogas plants as the primary cooking solution among households that currently use self-built traditional stoves, in particular, appears to be the most feasible and reasonable target in the nearer term.

Households owning at least one cattle and having sufficient space to install biogas plants can benefit largely from the biogas plants. Analyzing the current cooking status along with available resources, the awareness level of people, lifestyle, willingness to pay and the interest of the concerned Local Levels, a plan to shift to tier- 3 and above has been developed and presented in Table 3.

Table 3: Plan to shift to teir-3 and above technologies of local levels of Terai Distrcts

(In '000)

\begin{tabular}{|l|l|r|r|r|r|}
\hline S.N. & District & To ICS & \multicolumn{1}{|c|}{$\begin{array}{c}\text { To } \\
\text { biogas }\end{array}$} & \multicolumn{2}{|c|}{ Induction } \\
\cline { 3 - 6 } & & $\begin{array}{c}\text { From } \\
\text { TCS }\end{array}$ & $\begin{array}{c}\text { ICS/ } \\
\text { ICS }\end{array}$ & \multicolumn{1}{c|}{$\begin{array}{c}\text { ICS/ } \\
\text { ICS }\end{array}$} & $\begin{array}{c}\text { From } \\
\text { LPG }\end{array}$ \\
\hline 1. & Jhapa & 48.19 & 27.23 & 9.17 & 42.26 \\
\hline 2. & Morang & 37.08 & 26.24 & 7.02 & 57.07 \\
\hline 3. & Sunsari & 39.79 & 9.26 & 8.01 & 49.89 \\
\hline 4. & Udaypur & 26.24 & 11.70 & 1.47 & 8.04 \\
\hline 5 & Siraha & 35.94 & 8.90 & 5.88 & 15.76 \\
\hline 6. & Saptari & 25.34 & 16.45 & 3.51 & 10.41 \\
\hline 7. & Dhanusha & 33.57 & 18.07 & 4.44 & 13.65 \\
\hline 8. & Bara & 29.26 & 7.00 & 5.10 & 5.57 \\
\hline 9. & Parsa & 28.36 & 5.12 & 5.69 & 10.45 \\
\hline 10. & Rautahat & 40.55 & 14.34 & 7.42 & 8.16 \\
\hline 11. & Sarlahi & 36.71 & 15.65 & 10.05 & 12.88 \\
\hline 12. & Mahottari & 25.81 & 11.35 & 6.64 & 10.36 \\
\hline 13. & Chitwan & 6.66 & 3.57 & 3.53 & 21.31 \\
\hline 14. & Banke & 30.58 & 6.63 & 4.10 & 21.40 \\
\hline 15. & Bardiya & 42.36 & 12.33 & 5.95 & 6.12 \\
\hline 16. & Dang & 39.46 & 10.65 & 9.69 & 20.99 \\
\hline
\end{tabular}

\begin{tabular}{|l|l|r|r|r|r|}
\hline S.N. & District & To ICS & \multicolumn{1}{c|}{$\begin{array}{c}\text { To } \\
\text { biogas }\end{array}$} & \multicolumn{2}{|c|}{ Induction } \\
\cline { 3 - 6 } & & $\begin{array}{c}\text { From } \\
\text { TCS }\end{array}$ & $\begin{array}{c}\text { ICS/ } \\
\text { ICS }\end{array}$ & $\begin{array}{c}\text { ICS/ } \\
\text { ICS }\end{array}$ & \multicolumn{1}{c|}{$\begin{array}{c}\text { From } \\
\text { LPG }\end{array}$} \\
\hline 17. & Kapilvastu & 26.41 & 9.88 & 9.88 & 6.15 \\
\hline 18. & Rupandehi & 24.79 & 7.73 & 11.95 & 29.71 \\
\hline 19. & Nawalpur & 12.12 & 3.08 & 8.04 & 10.77 \\
\hline 20. & Parasi & 10.42 & 3.74 & 3.39 & 8.61 \\
\hline 21. & Kanchanpur & 23.54 & 6.23 & 4.22 & 14.52 \\
\hline 22. & Kailali & 56.64 & 14.63 & 4.50 & 12.52 \\
\hline & Total & 679.84 & 249.75 & 139.67 & 396.62 \\
\hline
\end{tabular}

On the basis of availabe resources, and plan of the local level plan, Chitwan has lowest potential of 6,500 to replace TCS by ICS and Parasa has highest potential of 86,000 . The potential shift from traditional cookstove toward improved cookstove in Terai has been found 738,000 .

Biogas is more cleaner fuel. Middle level can afford for biogas technology. It costs around NPR 70,000 and there is government subsidy for biogs construction. In Chitawan, Nawalpur and Parasi there is 3,000 biogas installation possibility in each disrtics from TCS to biogas. Jhapa and Morang have around 25000 biogas can be installed by replacing biomass based cookstove which is highest among the Terai. The potential shift from biomass cookstove toward biogas has been found 263,760 in Terai.

The shift of TCS/ICS towards induction in higher range disrtics of Parsa, Sarlahi and Rupandehi can be promoted above 10,000 . In most of the disrtics, transiton possibility from TCS/ICS to induction stove is very low. This is due to poor economic status of people. on the other hand, most of the Terai peole use LPG. There is high possibility towards the shift of induction stove from LPG. Udaypur, Bara, Rautahat, Bardiya, Kapilvastu, Parasi have lower potential district to shift towards induction stove from LPG. These disrtict less then 10,000 induction cookstove can be promoted by replacing LPG. In morang more than 50,000 LPG can be replaced by induction. About 407,000 induction stove can be used by replacing LPG in toral Terai.

\section{CONCLUSIONS}

- In Terai Districts, grid connected, biogas potential and fuelwood available households have been found $89.6 \%$, $44 \%$ and $45 \%$ respectively.

- Maximum national grid connected household is $98 \%$ in Sunsari District and minimum 67\% in Udayapur District

- Biogas potential has been found maximum in Udayapur District and minimum in Parsa District with $74 \%$ and $24 \%$ respectively.

- Current status of TCS, ICS, Rocket stove, Biogas stove, Kerosene stove, LPG stove and induction stove have been found 1,600,000; 37,000, 6,000, 90,000; 17,000; $1,107,000$ and 12,000 households respectively.

- Total potential ICS promotion by replacing TCS has been found 679,8400 . 


\section{Status and Prospect of Clean Cookstoves in Terai Region of Nepal}

- Biogas promotion potential by replacing ICS/TCS has been found 249,750.

- Similarly, Induction promotion potential by replacing ICS/TCS and LPG have been found 139,670 and 396,620 respectively.

\section{ACKNOWLEDGEMENT}

The authors gratefully acknowledge the support from Alternative Energy Promotion Center, Mid Baneshwor, Kathamdnu for their continuous support. Finally, we would like to thank the editor and all reviewers for their helpful and incisive comments.

\section{REFERENCES}

[1] J. Bronowski, The Ascent of Man. Little, Brown \& Company, 1973.

[2] IEA, "International Energy Agency. World Energy Outlook 2012-Executive Summary. France, November 2012. 〈 http://www.iea.org/publications/freepu blications/publication/English.pdf $\rangle, " 2012$.

[3] A. Warwick, H. and Doig, "Smoke: the Killer in the Kitchen, Indoor Air Pollution in Developing Countries, ITDG Publishing, London.," 2004.

[4] M. P. Kshirsagar and V. R. Kalamkar, "A comprehensive review on biomass cookstoves and a systematic approach for modern cookstove design," Renew. Sustain. Energy Rev., vol. 30, pp. 580-603, 2014, doi: 10.1016/j.rser.2013.10.039.

[5] S. Joshi, "ocio-economic impact of solar home system on the rural people of Nepal:A case study of Dhading District. An Unpublished Dissertation on Central Department of Rural Development.," S, 2010.

[6] M. A. Haines A, McMichael AJ, Smith KR, Roberts I, Woodcock J, "Public health benefits of strategies to reduce greenhouse-gas emissions: overview and implications for policy makers. Lancet 2009;374(9707): 2104-14, http://dx.doi.org/10.1016/S0140-6736(09)61759-1,"

2014.

[7] F. S. Venkataraman C, Habib G, Eiguren-Fernandez A, Miguel AH, "Residential biofuels in south Asia: carbonaceous aerosol emissions and climate impacts. Science 2005;307(5714):1454-6, http://dx.doi.org/10.1126/ science.1104359.," 2005.

[8] D. M. Kammen, R. Bailis, and E. Kituyi, "Greenhouse Gas and Particulate Emissions and Impacts from Cooking Technologies in Africa Greenhouse Gas Implications of Household Energy Technology in Kenya," no. December, 2003.

[9] S. C. Bhattacharya and P. Abdul Salam, "Low greenhouse gas biomass options for cooking in the developing countries," Biomass and Bioenergy, vol. 22, no. 4, pp. 305-317, 2002, doi: 10.1016/S0961-9534(02)00008-9.

[10] Manoj Kumar, Sachin Kumar, and S. K. Tyagi, "Design, development and technological advancement in the biomass cookstoves: A review," Renew. Sustain. Energy Rev., vol. 26, pp. 265-285, 2013, doi: 10.1016/j.rser.2013.05.010.

[11] S. Pradhan, "No Title," Impact ICS Rural livelihood A case study Siwalik Area Chulachuli VDC Ilam Dist., 2006.

[12] M. A. Johnson et al., "Impacts on household fuel consumption from biomass stove programs in India, Nepal, and Peru," Energy Sustain. Dev., vol. 17, no. 5, pp. 403-411, 2013, doi: 10.1016/j.esd.2013.04.004.

[13] CBS, "Central Bureo of Statistics," 2011.

[14] AEPC, "No Title," 2019, [Online]. Available: https://www.aepc.gov.np/improved-cooking-stoves.

[15] P. G. R. Dralami, Hari Bahadur; Ale, Bhakta Bahadur, "Assessment and optimization of thermal efficiency of two pot raised mud improved cookstove with variation of different parameters," J. Eng. Appl. Sci., 2018.

[16] WECS, "Energy Situation and Supply Conditon of Nepal," Water Energy Comm. Secreteriate, 2014.

[17] WECS, Energy sector synopsis report, Water and Energy Commission Secreteriate, Governmnet Nepal, Simhadarbar, Kathmandu, Nepal. 2012.

[18] N. Bhattarai and S. Risal, "Barrier for Implementation of Improved Cook Stove Program in Nepal," J. Inst. Eng., vol. 7, no. 1, pp. 116-120, 1970, doi: 10.3126/jie.v7i1.2069.

[19] AEPC, "Renewable energy hand book. Lalitpur: Alternative Energy Promotion Center.," 2010.

[20] WECS, "Energy Sector Synopsis Report; Perspective Energy Plan," 1994.

Hari Bahadur Darlami works at Tribhuvan University Institute of Engineering, Pulchowk Campus, Lalitpur. He has involvement in energy sector since 15 years. He is working in mechanization of agriculture sector. He has more than 20 publications.

Suvita Jha works at Kathford International College of Engineering and Management, Tribhuvan University, Nepal since 10 years. She is doing reaserach and development in economic analysis. She has more than 20 publications.

Bhishnu Kumari Budha woks at National Basic School, Kathmandu, Nepal. She is involving for socio economic analysis. She has more than 10 publications. 